\title{
The Importance of Nepotym and Corruption Management in Institutions and the Economy of the Country
}

\author{
Driton Fetahu, PhD Cand. \\ European University of Tirana, Albania
}

\begin{abstract}
:
Social, political and institutional factors play a major role in the country's economic development and economic growth in developing and developed countries. Corruption, which is a symptom of deep institutional weaknesses, is one of the factors responsible for reducing investment and spending (for education and health), increasing income inequality, decreasing foreign direct investment, and allocating resources. It tends to grow faster than the dynamics implemented to neutralize it. Systematically, it has caused many disturbing problems in all countries of the world. Based on a Transparency International report. Corruption is one of the greatest contemporary challenges of the world. It determines good governance, leads to inefficient resource allocation, disrupts the private and public sector, and often affects the poor. The people in the world carry the phenomena that society has so far encountered but has neglected. Nepotism usually means hiring close relatives, close friends, regardless of their merits and abilities. While corruption poses a permanent threat to both the economic system and the country's legal system. The purpose of this paper is; To assess the factors that have influenced the appearance and development of nepotism and corruption. Then, analyze the influence of nepotism and corruption in the country's economy. The impact of nepotism on employment and the advancement of relatives in the important sector of the country as well as the influence of corruption and nepotism in justice institutions. The research results will be useful for researchers who will be concerned with analyzing the influential factors of nepotism and corruption.
\end{abstract}

Keywords: management nepotism, corruption, justice institutions, the country's economy.

\section{Introduction}

"Corruption is bad, not because money and benefits change hands or because of the motives of the participants, but because it privatizes particular aspects of public life by creating different debates and problems." -Dennis F.Thompson, (1993)

The economy is generally in the phase of intense globalization, which does not only mean the interdependence of interregional economies, but also technological integration, as well as the profound structural changes that tend to dominate supersofted sectors such as high telecommunication equipment.

It is understood that these changes affect production in the first place and cause significant changes throughout the business process. This shows that they do not arise in themselves but are a factor in the changes of the surrounding environment that surrounds us.

In the world's largest encyclopedia on liga, Vikipedia, (see www.wikipedia.org), the word "manage" comes from the word "manegiare" (Ang.to handle-hendling, Train training or horse trainer - training space), which is derived from the Latin word which in translation means "hand."

While the word "Nepotism" comes from the "nepot" Italian, that is, the grandson, which has come into use by the papacy practice of granting special favors to their grandchildren or their relatives. So favoring relatives on the basis of family ties, namely nepotism, means hiring close friends or close friends, regardless of their merits and abilities (Dictionary, 2013). Nepotism can occur in different areas of organization of society (Nepotism, 2013). Nepotism exists all over the world, but nowhere does it dominate the political, economic, social and all-inclusive life as it is supposed to; The countries of Eastern Europe, southeastern Europe, the Middle East, even in some EU countries. According to the Strasbourg Convention (1999), 
corruption threatens legal norms, democracy, human rights and freedoms, undermines the rule of law, social justice and honesty, deforms fair competition, curbs the economic development and the moral foundations of society.

The notion of corruption derives from the word "corrumpere" which means taking bribes, bribes etc. The word corruption is derived from Latin, and the literal meaning is corruption, defiance.

Mere defamation, "Corruption is the misuse of trusted power for personal gain." Corruption is a multi-dimensional issue. In a narrower sense, corruption can be defined as: any violation of the duty of official persons or persons responsible for legal entities and any activity of initiators or beneficiaries of this conduct in return for a service that is directly or indirectly promised, Given, sought, received or expected to be taken for yourself or for another person.

This definition includes active and passive corruption, such as: for official persons who have a public function or exercise a public service, persons responsible for the management and administration of companies and persons who are initiators of corrupt behavior. Many individuals misunderstand corruption. Some give a sense so close that they match the term myth, bribe, and some others every action of life associated with corruption. Both attitudes are wrong.

Thus a definition of corruption would be as follows: Corruption is a deviation from the duty, law, rule, or ethical norms of an official or a public institution in favor of the beneficiary of this behavior which is influenced by a reward, promise, preferential treatment, Offered, given, requested or received. Corruption also means damage to public interests at the expense of individuals' interests, or preferential treatment of a group of individuals who may belong to the same political party. So the term corruption is not a term that only includes bribery and bribery but also includes other forms.

The reward is not meant to be in cash, but it may also be a preferential treatment with regard to employment, the performance of any service, or the promise given for any work done. Usually, political party representatives promise employment to individuals who have served the party to win the elections. Corruption and its impact on economic growth are accomplished during their government mandate. In this case, employment rules, law and ethical norms are violated because the evaluation criteria are not respected, such as merit employment, interviewing, testing, etc.

In some cases, the term corruption is also interpreted as Alienation. Corruption or Alienation is a phenomenon during which the elements or attributes of an element of a community are alienated to another community. The problem is not the lack of alternatives, as the definitions of corruption are numerous, but to choose one that is complete, unique and at the same time comprehensible. These three criteria are needed to minimize the risk of misunderstanding. We have therefore chosen to use the following definition: corruption. We have: when a state administration employee motivated to have private benefits treats individuals preferentially when this is not legally permissible.

The term "Corruption" has been given a great importance especially during the twentieth century, as this phenomenon significantly affects the economic performance of countries and especially in developing countries. Various studies on the consequences of corruption point out its negative impacts on economic growth (Klittgard, 1988; Shleifer and Vishny 1993; Mauro 1995; Bardhan 1997). The World Bank study in 1995 identifies corruption as one of the key obstacles to the economic and social development of the poor.

Corruption is a phenomenon just as old as mankind itself. It is found in all environments, in all systems and possible regimes, constituting a threat to them, especially for democracies. In the twentieth century it is also called white crime, since it is difficult to find and punish it specifically. It fits all situations by surviving even during the campaigns organized against it and is considered as: Misuse of power or position for personal gain. In a narrower sense, corruption can be defined as: violation of duties by public officials or responsible persons of legal entities and any activity of initiators or beneficiaries of this conduct in exchange for a service that is directly or indirectly promised, offered, provided, sought, received or expected to be obtained for itself or for another person.

A human activity, regardless of whether it is state, private or non-profit, whether it is developed in America, Italy, Japan, Russia or Albania, tends to turn into a corrupt activity if a person (or a group of individuals), Have monopolized the power over a commodity or service, enjoys the freedom of judgment and action to establish the offer and the price of such goods or services and this person (or group of individuals) does not account for anyone (bears no responsibility) for the development of the activity .

For Kregar (1997), corruption is a pathological phenomenon, systematic operation in which the ruling political class places personal interest on the political community. Corruption is a phenomenon that has been found in both developed and 
developing countries, but at different levels, and it can be noticed a higher trend among the poorest countries in corruption than it is present in developed countries. Corruption as a phenomenon is widespread worldwide, both in developed countries and in developing countries. But market places and centralized economies have faced more.

In the past and in the current period (Mihaiu and Opreana, 2013From a legal perspective, distinguish two types of corrupt behavior, active corruption and passive corruption). We are aware that corruption, with a large or small extent, is a threat to all participants in a democratic society, especially for countries that are for a period of transition. Corruption is fought and put under control in the moments that it has emerged.

The reason why it is easy to fight corruption at the time of its appearance is that it is very easy to identify and prevent. More generally, corruption has a degrading effect on the overall system and social order. The limits of corruption are as inaccessible as human greed is unattainable. Human greed grows when the justice system does not work.

The offense of corruption is related to the violation of legal provisions and the code of professional ethics by employees in the public or private sector. According to Antonić (et al., 2001), corruption is manifested in different fields and in different ways. As an illustration, it may only focus on some forms of corruption in the judicial system, police, customs, health, and corruption of local authorities. But Halimi (2014), in his article titled; 'Corruption of cancer of Kosovo society', corruption is a factor influencing the destruction of the country's economy.

Corruption has been present and constitutes one of the worst problems of the past decades, but over the last decade has shown a great interest from academics and policy makers. Corruption has been a widespread and repeated phenomenon in human history. He has been present in all political and social systems, in different levels and forms. Hammurab's XVIII century code p.e.r. Specifies legally based punitive measures against corrupt officials, particularly for judges' corruption. In the 4th century BC, Kaulitiliya, Prime Minister of the Kingdom of India, wrote the Arathasastra book in which he also discussed corruption. Aristotle, Plato, Machiavelli and Ruso have studied government corruption. Dante put the deceased into the deepest hell, reflecting the medieval abomination of corrupt people. Shakespeare has given corruption a prominent place in some of his works. Known politicians (presidents, prime ministers, ministers) have lost their positions due to corruption and in some rare cases, the political class has been completely replaced.

Corruption is a devilish activity that is caused by the psycho-social shortcomings of adulterous behavioral norms, which are designed to produce advantages or benefits for themselves, the family or friends, friends or political allies. Corruption is a concept. With many meanings or a set of unambiguous concepts that are part of economic, political, psychological and mathematical sciences. There are several reasons why this phenomenon has shown a high interest: first, a consensus is reached that corruption is a unique and universal phenomenon. It is present both in poor and developed countries, in the public and private sectors as well as in non-profit organizations. (World Bank 1997).

Second, the scandals resulting from corruption have played an important role in the political sphere in recent years. For example: crashed governments as well as corrupt political figures or the destruction of the reputation of organizations and businesses

Powerful as a result of conducting corrupt affairs. A good illustration of them is the collapse of Marcos's government in the Philippines (New York Times, Feb. 26, 1986) and the destruction of the Enron Corporation in the US (Healy and Palepu, 2003). Shleifer and Vishny (1994) have noted that in Greece there is a high diversity of employees and leading corporations when the opposition party wins.

Thirdly, as well as the most important problem is that corruption can be an obstacle to the country's economic development and has a direct impact on its economic growth. In transition countries, transition from a centralized economy to a free market has created room for ineligible benefits. It is seen to be accompanied by a shift from a well-organized corruption system to a more chaotic system (Shleifer, 1997). Low economic growth has been present in some countries as a result of institutional malfunctioning and the proliferation of corrupt officials.

In the popular sense, corruption is the Abuse of State Position to Provide Unlawful Benefitsll. The catalog of corrupt activities involves bribery, intimidation, exerting influence, exploiting another's property or property, speeding up or deliberately slowing down the job or favoring it by paying money, deceiving, revealing secret or confidential information, nepotism, etc. . Corruption exists not only in state institutions of different levels, but also in the private sector and in international organizations. So in the metaphorical sense, corruption is expressed by the formula: 


\section{$K=M+L-P$,}

$\mathrm{K}$ - shows corruption, $\mathrm{M}$ - shows monopolization of power, $\mathrm{L}$ - shows the freedom of judgment and action, while $\mathrm{P}$ - shows the responsibility.

Improving governance is essential for the country's economic development and improving the livelihoods of poor individuals. But both of these main objectives are threatened by corruption. There should never be underestimated the urgent need for corruption to support political forces. Corruption is also helped and encouraged by the long standing power of the same political party. A prominent scientist in corruption theory (S. Rose-Ackerman, R.)

Nepotism can occur in various fields including: Political Nepotism; Family nepotism; Nepotism in the organization; Nepotism in employment / advancement. Political nepotism affects the giving of special favors to public organizations of political associates. For the Institute for Development Policy (2014), the politicization of public organizations has brought the first consequences.

Appointing political people on boards of public organizations. Now, the phenomenon of political nepotism has taken root in the provincial and provincial mentality in society, and it is no less harmful than family nepotism. This phenomenon, apart from political thought, has been installed in the wider population as well. Demi, A., (2014), estimates that the politicization of public organizations has started since the declaration of Kosovo's independence.

The favoring of relatives on the basis of family ties, which is more precise means nepotism, in one way or another in most cases enables the relatives to work without merit and adequate qualification, with later consequences for the institution and the society itself. According to the Kosovo democratic institute (2014), central public organizations have been the most suitable place for rehabilitating and settling party militants.

Political and family influences influenced the employment of approaches, in different positions in public and state institutions, employment included all relevant sectors of the country as well; Employment in public administration, employment in leading staff in ministries, employment of relatives in departments, important sector of the country, employment in security organs, employment in state agencies, employment in public corporations, employment in public media (Fetahu, D, 2016). According to Cohu (2007), the total politicization of administration is taking place in Kosovo, which is in full contradiction with the European criteria for reforming and building civilian administration, and such continuation will deepen the economic crisis in Kosovo and undermine sustainability Its economic and political-social. Ruling political parties to engage people close to politics and on a clientelist basis have been a phenomenon of all those political forces that have been in power over the years. Unsustainable employment has (had) negative impact on the country and beyond.

Hence, not setting preliminary criteria for employment, but employment by group, tribal, or clan influences on the arrival of people without merit, with a negative impact on; The country's economy, the integration, with a negative impact on justice, as well as a negative impact on society itself.

With which criteria, the criteria and conditions for establishing employment relationships would be determined, where without the fulfillment of the criteria, no admission to work, the fulfillment of employment or advancement criteria, were done almost none As appropriate, this had implications for the advancement of the HR and the development of the public sector. So, on the "criterion" of nepotism and non-professionalism it has been impossible to create genuine state bodies and officials as well as the professional administration.

Because, only a strong and professional administration led by people with the most appropriate experience could successfully build economic development field and in every area of life. Perhaps, we have not encountered anywhere in Europe, that in state and government bodies hiring and appointing officials in leading political and economic positions without public competitions, through which realistic assessment of staff according to their professional experience and skills.

Eliminating the impacts of family ties, as has happened and is still happening in the Balkan countries especially in: Kosovo, Albania, Macedonia, Montenegro, B \& H, etc. Family nepotism (clan) is many times present, ranging from appointments to the highest state positions and to the lowest levels of municipal administrations. To take only the example of appointment of senior public / state officials, we will understand that almost no one has been named on the basis of the fulfillment of the conditions foreseen by law, respectively the competition, to be appointed or elected in these posts, The minimum of work experience. 
In Kosovo mistakes in employment began with the deployment of the international administration (UNMIK, 1999). And here is the fatal mistake that UNMIK has done together with the Kosovo government afterwards. Because instead of issuing provisional normative acts as well as legal employment conditions, ranging from the mere referral to the position of the president of the country, making the professional selection of competitors to be admitted to work , What is happening to this day is the continuation of employment and appointment of people, not according to legal and professional norms, but on the basis of family nepotism.

But this has also happened in some public, diplomatic representations of most of the countries of the southeast Balkans. For Abdala, M. (et al, 1994), if employees are in competition with a privileged individual, their probability of advancement is rather low. Therefore, given the legal violations that have been made in terms of hiring people without merit and

Without meeting the competitive criteria, we should not be surprised why today in these countries dominates an economically backward, poor-to-extreme population, unemployed youth. Kayabaşı, Y., (2005) thinks that the phenomenon of preferential treatment is and is considered a "form of corruption" that appears in the political decision-making process, and is at the same time one of the main problems of public bureaucracy.

Nepotism within organizations when a person is employed because of their family ties. It is generally seen as unethical, both by the employer and the employee. According to the Institute for Development Policy (2014), the appointment of political boards has influenced these people to make room for other militant political parties, risking their full capture of party elements.

The presence of a high degree of risk in business, and unfair competition in the market in which organizations are operating, is increasingly affecting the economic stability of organizations and businesses (Fetahu D., 2014). Corruption is causing no trade equity by affecting the favoritism of certain businesses. As a result of corruption is increasing the cost of doing business in these countries, this is affecting the creation of a climate that for many businessmen is considered a difficult condition to stay active in the market. For Eigen (2004), the countries in the region have a multitude of anti-corruption laws, but they also have judges appointed and beholden to politicians who are selective about enforcing these laws. What good are these laws when crooked politicians know they will not be applied.

Switching from one system to another political system has impacted to a large extent has influenced the personal ethics of the citizens of the country. Therefore, the desire for the illicit profitability of the property is not incidental, it is the result of the slow action of the law, the act of justice with delay or at all (Fetahu D. 2014).

Switching from one system to another political system has impacted to a large extent has influenced the personal ethics of the citizens of the country. Therefore, the desire for the illicit profitability of the property is not incidental, it is the result of the slow action of the law, the act of delayed justice or the law does not act at all (Gjinovci A., 2015). But why should corruption be present in transition countries that are already economically crushed?

In countries, transition societies face;

- Demands for liberalization of the economy.

- Great social transformations.

- Property transformations.

- Lack of laws.

- We are dealing with legal loopholes (issued with or without purpose).

Low salaries of state administration officials.

- Abuse of official position is already in the trend, but in almost all countries

Southeast Europe.

- Citizens' requirements to live better.

- Corruption now takes galoponte proportions, and with the available mechanisms 
- and the climate that is dominating the citizens is hard to curb (Fetahu D.2014).

\section{Research Objectives}

This paper is based on the fulfillment of several objectives as follows:

- Information on nepotism and its impact on institutions, the country 's economy and

wide;

- Information on corruption and its impact on institutions, the country's economy

- and more;

- Theoretical treatment of nepotism and corruption and their management.

\section{Purpose of the study}

In this study, research into nepotism and corruption has been conducted and managed with this deviant phenomenon. This paper aims to fulfill the following goals:

- Assess the factors that have influenced the appearance and development of nepotism;

- Assess the factors that have influenced the occurrence and development of corruption;

- Analyze the influence of nepotism and corruption in the country's economy;

- The impact of nepotism on employment and advancement of relatives in important sectors

Of the country; impact of corruption and nepotism in justice institutions. The research results will be useful for researchers who will be concerned with analyzing the influential factors of nepotism and corruption.

\section{Research questions}

The research questions underlying the study are:

1. What is the impact of nepotism on the country's economy and how to manage it?

2. What is the impact of corrosion on the country's economy and democracy and which management methods are more favorable?

\section{Hypotheses}

The hypothesis of the study in this topic based on the research questions raised above

They are:

1. Nepotism and corruption are presented before 1999 and how to manage them;

2. Nepotism positively affects the country's economy;

3. Nepotism and corruption were introduced after 1999;

4. Nepotism and corruption have a negative effect on the economy and democratic institutions of the country.

\section{Methodology}

Literature in the field of management and corruption and nepotism has been used for the preparation of this publication, with particular emphasis on the use of research in this area, as well as the use of the materialist collected from the documents as well as the results of the respondents who are involved in this research. Based on the specifics of this research, combined research methods, such as quantitative and qualitative research, have been used.

Sample selection is based on the following criteria: 
A) Explore literature and publications on nepotism in Kosovo,

B) Investigate literature and publications on corruption in Kosovo.

Participants' data, reports and surveys have been analyzed in detail in order to create a clearer picture that is related to the research.

\section{Research results}

\subsection{Influence of nepotism in the country's institutions}

Nepotism is a common accusation in politics when a close relative of a powerful political figure rises in power without possessing relevant qualifications. Nepotism as a term implies giving special favors to grandchildren or relatives. But the phenomenon of political nepotism has taken root in the provincial and provincial mentality in society, not even

Is nothing less harmful than family nepotism. This kind of nepotism, where leaders have been and remain the main pillar around which myths and political programs have been built on the basis of nepotism and political ideology according to the regional and kinship affiliation of the leader. This type of nepotism is undoubtedly the essence of failure in many political subjects, which continue to be identified with the leader and party leader. Of course, politicians must give their votes and support in their own merits and experiences in political life, not political political nepotism, because such a localist "criterion" and logic in politics is not practiced by any legal and democratic state in Democratized countries and especially in a part of the countries of Europe that have already experienced these problems. This phenomenon, apart from political thought, has been installed in the wider population as well. Thus, favoring relatives on the basis of family ties, which means more precisely, means nepotism, in one way or another in most cases enables the employment of relatives without merit and adequate qualification, with consequences for the institution and the society itself. Political and family influences influenced the employment of approaches, in different positions in public and state institutions, employment included all sectors of the country such as: employment in public administration, managerial staff in ministries, employment of relatives in departments, important sector of the country, employment in security organs, state agencies, public corporations, and in public media.

The state itself as a cause for corrupt practices:

The main contributor to corrupt practices may be the state itself, mainly when it does not pay its bills. For example, a recent check in Russia (the first of its kind in the last 20 years) showed that Primorit's universities were raising money from students in the form of illegal payments such as library registration fees, or postponing students to pay Large sums in favor of "charitable funds". At the State Academy of Economics and Management in the Far East, each of the 4,500 students contributed $\$ 200$ a year to the charity fund; Payment for unspecified student needs this amount.

Represents the 5-month average income in Primor). Even those who have a free study pay this amount. Some universities ignore the benefits that Orphans and Corruption students need to take and their impact on Unemployment Growth 15. Gennady Turmov, Rector of Primary Technical University, said the government should blame for not financing colleges, forcing them to seek money elsewhere.

From the above, the causes of corruption can be grouped in institutional and social reasons. Among the institutional causes we can mention: broad authority and multiple powers, low accountability and lack of transparency, incentive policies that do not motivate (salaries, performance bonuses, job security and professionalism are at a low level, salaries and bonuses are not standardized).

In social causes we can mention: personal dedication, an unreliable government, inequality and discrimination, etc.

For countries that are going through the transition process, which normally involves our country, we can mention some specific causes of corruption as follows: appropriate conditions, risks of any kind (health insurance, accidents, unemployment, poverty) are high, risk distribution mechanisms are weak (insurances, underdeveloped labor market good). Not only is the lure stronger, but the possibilities are more numerous.

Monopoly benefits are too high, the economic bribery is too large because the amount of assets, once state owned, and marketed for privatization to give to the one who offers the most (under the hand) and the least legally. Corruption and its 
Impact on Growth 16. The discretionary power of many officials is huge, while the legal framework is often unclear, in frequent and continuous change and poorly dispersed through various publishing and information mechanisms.

Accountability is generally poor, political competition and limited civil liberties, laws and ethical principles are little developed and legal instances charged with ensuring their respect are not properly prepared for this complex task. Counterparts providing data on which law enforcement and law enforcement are based are often weak and unprofessional. A paradoxical fact is the privatization process, as generally, although the privatization process, in the last analysis, reduces corruption by reducing state interventions in the economy, and in transition countries has been one of the main sources of corruption.

From a survey conducted in our country has resulted that the main factors influencing the spread of corruption are: low salaries $67.5 \%$, rapid personal enrichment by people in power $49.0 \%$, lack of strong administrative control $40.6 \%$, combining official duties and personal interests $33.3 \%$, legislation not perfect $28.8 \%$, the moral crisis in the transition period $24.5 \%$, problems inherited from the communist past $20.7 \%$, inefficiency of the judicial system $19.5 \%$, specific features of Albanian national culture 7.6\% Source: Coruption Survey 2011.

\section{When is nepotism introduced in Kosovo?}

Field research was done to identify nepotism; Manner and period of submission. Field research results show that only $40 \%$ of respondents agree that corruption has been present before 1990 , though $60 \%$ of them do not know if there were corruption during those years. Though, $40 \%$ of respondents fully agree that nepotism has been present after the 1990 s.

\section{When did nepotism occur in Kosovo?}

Based on the findings of the field we conclude that nepotism before and after years has been very little present in local institutions. But there are field findings that show that $80 \%$ of respondents agree that nepotism has emerged after the deployment of the international administration in Kosovo (UNMIK). While $60 \%$ of respondents think that nepotism has come up after the declaration of independence

Table No. 1;

When did nepotism occur in Kosovo? Yes No I do not know!

Before the 90 s, $40 \%$ / $60 \%$

After the 90 s $40 \% 20 \% 40 \%$

After the war during the UNMIK administration $80 \% 20 \%$

After Kosovo's declaration of independence $60 \% 20 \% 20 \%$

Source; Author (2016).

Based on the research results, we conclude that nepotism has been introduced and developed over international administration and continued after the country's declaration of independence. But how does nepotism affect the country's economy?

The vast majority of respondents think that nepotism has a negative impact on the country's economy. As a phenomenon of nepotism is affecting the employment of non-professionals, this is negatively affecting the economy, the country's politics. Since there are jobs under political influence, this is affecting poor diplomatic representations.

Table 2:

How does nepotism affect the country's economy? Yes No I do not know!

Nepotism positively affects the country's economy? 20\% $80 \%$ /

Nepotism is affecting hiring non-professionals? $100 \%$ //

Employment in Kosovo is difficult without external support / politics? 60\% / 40\% 
Nepotism has affected to have weak diplomatic representations? 100\% //

Nepotism is affecting the employment / advancement of relatives in the important sector of the country? $80 \% / 20 \%$

Source; Author (2016).

Research results show that nepotism is affecting employment and advancing relatives in the important sector of the country, creating unprofessional and inadequate staff in the choice of the country's economic, political and social problems. This has led to a relative economic development that is not reaching young people's employment so earnestly. Insufficient economic growth is affecting the growth in demand for better life in Western European countries. This massive migration of the young population to the EU countries has created the impression that the country is being created in a workforce producer for EU countries with long-term consequences for families and the country's economy. As most of the people who seek economic asylum with EU countries lack the particular education / specialization that will help you find decent work places.

\subsection{The results of corruption impact research}

But what motivates officials to corruption, violation, and violation of the code of ethics by encouraging them to enter the sphere of corruption?

It is thought that there are many factors that influence access to the world of corruption. But what motivates them towards entering the sphere of corruption is; The desire to enrich as swiftly as possible; For the illicit profitability of the property which is seen as an easy enrichment form; The benefit of any personal, family, or privilege interest, the enjoyment of any right or advancement at high levels of the hierarchy, etc.

\section{When did corruption occur in Kosovo?}

Field research shows that all respondents think that corruption in Kosovo was postponed after the deployment of the international administration in Kosovo (UNMIK, 1999), and this opinion is shared by $100 \%$ of respondents. While $80 \%$ of respondents think that after the announcement That corruption is exposed to independence, while $100 \%$ of respondents think that the deployment of EULEX has no influence on reducing corruption.

Table 2;

When did corruption occur in Kosovo? Yes No I do not know!

After the deployment of UNMIK $100 \%$ / /

After Kosovo's declaration of independence 80\% / 20\%

After the deployment of EULEX Kosovo 100\% //

Source; Author (2016).

What is the impact of corruption on the country's economy?

Much of the respondents think that corruption has a negative impact on the country's economy, while $20 \%$ think that corruption has a positive impact on the country's economy. Indeed, the vast majority of respondents think that corruption is a leap for democratic institutions themselves. As a phenomenon, corruption curbs economic development, undermining the country's development processes. Corruption is affecting increased uncertainty, with negative impact on justice institutions.

Table no. 4;

How does corruption affect the country's economy? Yes No I do not know!

Corruption positively affects the country's economy? 20\% $80 \%$ /

Corruption is a threat to democratic institutions? 100\% //

Corruption curbs and undermines economic development? 100\% // 
Corruption is affecting the loss of local and foreign investors? $80 \% / 20 \%$

Corruption is affecting increasing uncertainty? $80 \%$ / $20 \%$

Corruption and nepotism have a negative impact on justice institutions? 100\% / /

Source; Author (2016).

\section{Conclusions}

Based on research, we understand that nepotism and corruption as a phenomenon has been present even before the 1990s, thus finding the country's monistic governance, but nepotism was more limited. But as a growing phenomenon, according to field research results, nepotism developed and increased especially after the 1999s, during the governance of the international administration (UNMIK). After declaring the independence of the country, no positive result was achieved in avoiding nepotism, although according to the results of the research it has been less present.

Problems that relate to nepotism are numerous;

- Nepotism is having a negative impact on the country's economy;

- Nepotism is affecting the employment of non-professionals, with implications for democratic institutions;

- Employment in Kosovo is difficult without support from politics;

- Nepotism has affected poor political, diplomatic representation;

- Nepotism is affecting employment and advancing relatives in the important sector of the country.

So the main concern for nepotism is that it opposes employee hiring and promoting the most qualified candidates for a job. While in the market we can encounter other candidates who can have high education, work experience. While, we are determined to hire a relative who does not possess the right qualities, and this can give the impression of a classic and detrimental nepotism.

Corruption poses a permanent threat to both the economic system and the country's legal system. Corruption is one of the greatest challenges of our time. It is a challenge that needs and can be met, but which requires engagement of ethical human resources that are scarce in southeastern Europe.

The research results show that:

- Corruption as a phenomenon has emerged after the deployment of the international administration;

- After the declaration of independence of the country, no major effort has been made in combating corruption;

- Also, the international mission EULEX, in spite of exclusive competencies, has not even made the least effort to fight corruption in the country.

Field results show that corruption is part of phenomena that are difficult to define, because its meaning varies depending on the time and the social and political context.

However, according to the findings:

- Corruption is adversely affecting the country's economy;

- It is a threat to democratic institutions;

- Corruption is increasingly inhibiting economic development;

- Corruption is affecting the loss of domestic and foreign investors; 
- Corruption is affecting economic, political and social insecurity;

- Corruption and nepotism have a negative impact on justice institutions.

\section{References}

[1] Against Corruption, Regional Conference of Central and East European Countries on Fighting Corruption, Bukurešt, pp-39.

[2] Boadi, G. E. (2000), "Conflict of Interest, Nepotism and Cronyism", Source Book 2000, Vol. 5, p. 195-204.

[3] Begovic, B., and Mijatovic, B., (2001),' Corruption u Sebiju”. Publisher; Centre for liberal Democratic Studies. Serbija, Belgrade.

[4] Demi, Agron, (2014), Analizë mbi funksionimin e Agjencive të Pavarura dhe Ndërmarrjeve Publike, baza ligjore e tyre, politizimi i bordeve udhëheqëse, si dhe raportet e tyre me institucionet themeluese, Prishtinë 2014.

[5] European integration, judiciary and fight against corruption, taken from http://www.cohu.org/repository/docs/Integrimi Evropian, Gjygesori dhe Lufta k under_Korrupsionit_10259.pdf, (seen 16.12.2013).

[6] Eigen P., (2004), The Judiciary, Law Enforcement and Society in the Fight Against Corruption, Regional Conference of Central and East European ACountries on Fighting Corruption, Bukurešt, pp-39.

[7] Gjinovci, A., Arsim (2016), Nepotism and economi crime, The role of nepotism and corruption in the economy. Publisher; LAP, Lambert Academic Publishing.

[8] Gjinovci, A., Arsim (2015), Economic Transformation and the role of privatization. The experience of developing countries in southeast Europe. Publisher; LAP, Lambert Academic Publishing.

[9] Gjinovci, A., Arsim (2014), Informal economy and ethics in management of human resources and business;the case study of Kosovo. Publisher; LAP, Lambert Academic Publishing.

[10] Halimi, A., (2014), 'Corruption "cancer" of society in Kosovo'. http://www.ekonomia-ks.com/?page=1,9,8531 (seen 20.10.2014).

[11] Institute for development policy (2014), Politizimi në ndërmarrjet publike lëshon rrënjët e tij. Prishtine, Kosove, 20/11/2015.

[12] Kregar, J., (1997), "The appearance of corruption'. Croatian year book of International Law and Practice, Vol. 4, pp- 26.

[13] Konjufca, Glauk (2012), Nepotizmi ka lëshuar "rrënjë" në Kosovë. Publikur nga Zëri i Kosovës, Dec 04, 2012, Prishtine, Kosove. http://zeriikosoves.org/nepotizmi-ka-leshuar-rrenje-ne-kosove/ (28.01.2016).

[14] Kayabaı, Yeltekin (2005), Politik Yozlamaya Çözüm Olarak Anayasal ktisat, Çukurova Üniversitesi Sosyal Bilimler Enstitüsü, Yayınlanmamı Yüksek Lisans Tezi, Adana.

[15] Mobingu dhe nepotizmi në Republikën e Kosovës (2014), Hulumtim i opinionit public, Publikuar nga: Instituti për Kriminologji dhe Kriminalistikë, Prishtinë, shkurt

[16] 2014, f-13-14. 17. Mihaiu Marieta and Opreana Alin (2013), "The public sector

[17] efficiency from prespective of corruption phenomen '. Revista Economica 65:1, Lucian Blaga University of Sibiu, pp 39.

[18] Mesko, G., and Petrovic, B., (2004),' Criminology". Publisher; Faculty of Law, Sarajevo, pp. 183 - 184.

[19] Nepotism (2013), Dictionary.com, Retrieved 20 June 2013. Nepotism at Work (2013), Safeworkers.co.uk. 201304-20. Retrieved 2013-06-20.

[20] Strasburg Convention (1999), "Criminal responsibility in the fight against corruption'. p.1 of paragraph 4 Strasbourg 17,01,1999.

[21] Sasic, Z., (1998)," Corruption and its suppression in the world and in Croatia'. Criminal aspect, Police and security. Croatia, Zagreb, 1-2/1998, pp. 3 - 4.

[22] UNMIK (2001), United Nations Interim Administration Mission in Kososovo regulation no. 2001/11, value added tax. http://www.unmikonline.org/pages/default.aspx.Zogiani, Avni (2012), Nepotizmi ka lëshuar "rrënjë" në Kosovë. Publikur nga Zëri i Kosovës, Dec 04, 2012, Prishtine, Kosove. 